\title{
BUDAYA ORGANISASI, PEMBERIAN INSENTIF DENGAN KOMITMEN KERJA KEPALA SEKOLAH MENENGAH NEGERI DI KOTA-KOTA DALAM PROVINSI SUMATERA BARAT
}

\author{
Oleh: Syahril \\ Universitas Negeri Padang
}

\begin{abstract}
The study was inspired by the low of work commitments of the principal in public secondary school at the cities in West Sumatera.The purpose is to determine the organizational culture and incentives as prediction factors work's commitments of the principal. Methodology Mixed methods research approach, in the form of embedded concurrent design or a combination of uneven. Population's studies is the principle of public secondary schools in the cities in West Sumatra province, amounting to 150 people. A sample of 116 people that taken at random. The research instrument was a questionnaire and an interview guide. Data processing is performed by multiple regression analysis and thematic. Results of data processing research indicates that organizational culture and incentives either individually or collectively can be used as a factor forecasters to work commitments principals.
\end{abstract}

Keywords: Culture, organization, incentives, work commitments

\section{PENDAHULUAN}

Masyarakat meletakkan harapan yang tinggi kepada sekolah dalam usaha membentuk individu yang berkualitas, berilmu pengetahuan, bermoral dan mempunyai kemahiran yang tinggi (Donaldson, 2006). Kesuksesan sekolah untuk mencapai harapan masyarakat tersebut ditentukan oleh banyak faktor, salah satunya adalah kepala sekolah. Kepala adalah orang yang diberi tugas dan tanggungjawab untuk mengelola penyelenggaran pendidikan di sekolah (Ubben et. all. 2005). Kepala sekolah adalah pemimpin yang bertanggungjawab terhadap berbagai aktifitas dalam penyelenggaraan pendidikan di sekolah. Sejalan dengan itu Drake dan Roe (1999), menyatakan bahwa setiap aktifitas yang dilaksanakan di sekolah merupakan tanggungjawab dari kepala sekolah. Prestasi dan kemajuan yang dicapai sekolah berawal dari kepemimpinan kepala sekolah yang cemerlang. Hal ini juga di sokong oleh (Glasser, 2004), yang menyatakan bahwa kualitas sekolah amat bergantung kepada kualitas kepala pada sekolah yang bersangkutan. Dengan kata lain, kepala merupakan penentu kecermelangan suatu sekolah. Ini juga diakui oleh Levin dan Lockheed (2001), yang mengatakan bahwa maju dan mundurnya sebuah sekolah ditentukan oleh kepemimpinan kepala sekolah. Selanjutnya Dessler, 2005 mengemukakan tidak ada sekolah yang menjadi maju dan cemerlang sekiranya kepemimpinan kepala pada sekolah tersebut lemah. Sebaliknya sekolah yang lemah atau jelek dapat bertukar menjadi sekolah yang berkesan dan berprestasi dengan kepemimpinan kepala sekolah yang berkualitas, (Hallinger dan Hack 1998). Pendapat di atas menunjukkan pentingnya peranan kepala dalam pengelolaan sekolah.

Sementara itu Sopiah (2008), mengemukan bahwa komitmen kerja merupakan prasyarat keberhasilan kepala dalam memimpin suatu sekolah. Tidak akan tercapai kesuksesan bagi seorang kepala sekolah tanpa disertai dengan komitmen kerja yang tinggi dalam melaksanakan tugas. Setiap orang dituntut untuk bekerja dengan baik dalam organisasi sesuai dengan kemampuan yang dimilikinya. Namun kemampuan saja belum sepenuhnya menjamin orang tersebut akan berhasil dalam melaksanakan tugas. Selain dari kemampuan, komitmen juga amat menentukan keberhasilan seseorang dalam bekerja. Komitmen kerja adalah keterikatan seseorang terhadap pekerjaannya. Robbins (2005) mengemukakan orang yang mempunyai komitmen, akan bekerja secara total dalam organisasi dengan memberikan segenap perhatian, fikiran, tenaga dan waktu yang dimilikinya terhadap pelaksanaan pekerjaan. Sebaliknya orang yang tidak mempunyai komitmen, meskipun dia mempunyai kompetensi yang bagus, dia akan bekerja setengah hati. Syaiful Sagala (2008) dan Mulyasa (2012), mengemukakan 
dengan tidak adanya komitmen kerja yang kuat, mustahil seseorang akan dapat melaksanakan tugas dengan baik.

Perlakuan negatif kepala terhadap sekolah seperti terlambat datang ke sekolah, pulang lebih cepat daripada waktu yang ditetapkan, tidak bersemangat dalam bekerja merupakan gambaran dari rendahnya komitmen kerja kepala sekolah (Burrows dan Wesson, 2001). Pendapat ini juga di sokong oleh Mowday et al. (2002), yang mengemukakan orang yang mempunyai komitmen kerja yang rendah, sering melakukan tindakan yang dapat mengurangi produktivitas kerja seperti memperlambat pelaksanaan pekerjaan, meninggalkan atau mangkir dari tempat kerja pada waktu pelaksanaan pekerjaan, mengutamakan kepentingan peribadi atau kelompok daripada kepentingan umum dan tidak mau bekerja melebihi waktu yang ditetapkan. Sebaliknya orang yang mempunyai komitmen kerja yang tinggi akan berperilaku yang menguntungkan bagi organisasi seperti bekerja dengan bersemangat, datang dan pulang dari tempat kerja sesuai dengan waktu yang telah ditatapkan, dan bersikap sebagai pelayan dalam bekerja.

Saat sekarang keadaan kepala sekolah terutama kalau dikaitkan dengan komitmennya dalam melaksanakan tugas masih amat menyedihkan, ini tergambar dari hasil penelitian Lieke (2009) dan Nurliana (2011), tentang komitmen kerja kepala sekolah. Hasil penelitiannya menunjukkan bahwa komitmen kerja kepala sekolah dalam melaksanakan tugas masih dalam katagori rendah. Temuan yang sama juga ditunjukkan oleh hasil penelitian Wanti Simanjuntak (2009) ; Imam Subandi. (2012) dan Mariatik (2013) terhadap kepala sekolah menengah atas di Jawa Timur, yang menunjukkan bahwa komitmen kerja kepala sekolah dalam melaksanakan tugas masih jauh dari yang diharapkan, hal yang terlihat dari rendahnya disiplin kerja kepala sekolah dalam melkaksanakan tugas. Hasil penelitian di atas menunjukkan bahwa komitmen kerja kepala sekolah masih perlu ditingkatkan, agar kejayaan dan kesuksesan dalam penyelenggaraan pendidikan dapat dicapai sebagaimana yang diharapkaan.

Khususnya di sumatera barat kepala dinas pendidikan pada peringatan hari Pendidikan Nasional 2 Mai 2013 mengatakan bahwa komitmen kerja kepala sekolah di sumatera barat masih amat rendah. Ini terlihat dari rendahnya kualitas guru di sumtera barat. Berdasarkan uji kompetensi yang dilakukan oleh Lembaga Penjaminan Mutu Pendidikan (LPMP) sumatera barat tahun 2013 terhadap guru yang mengajar di sekolah menengah atas di peroleh data bahwa rata-rata tingkat penguasaan guru terhadap kompetensi guru (kompetensi pedagogik, profesional, keperibadian, dan sosial) masih jauh dari yang diharapkan iaitu 42,25\%. Data ini menunjukkan bahwa kualitas guru khususnya di sekolah menengah atas di Sumatera Barat masih sangat rendah. Rendahnya kualitas guru tentu juga berpengaruh terhadap prestasi belajar siswa. Bedasarkan data ujian nasional 2013, prestasi siswa sekolah menengah atas di sumatera barat menempati urutan ke 17 dari 33 propinsi di Indonesia, (Laporan LPMP Sumatera Barat tahun 2013). Sementara itu hasil penelitian Ridho (2011), yang menemukan bahwa komitmen kerja kepala sekolah menengah pertama negeri di Kota Padang masih amat rendah, hal ini terlihat dari seringnya kepala sekolah meninggalkan kantor pada waktu bekerja untuk urusan yang kurang terkait dengan tugasnya, datang dan pulang dari sekolah sering tidak sesuai dengan jadwal yang ditetapkan, serta seringnya terjadi konflik di sekolah. Akibat dari permasalahan tersebut (rendahnya komitmen kerja kepala sekolah) sering terjadi unjuk rasa yang dilakukan oleh guru dan siswa, mereka menuntut agar kepala sekolah mundur dari jabatannya sebagai kepala sekolah, (Wahjosumidjo 2013). Rendahnya komitmen kerja kepala sekolah tersebut jelas akan mengganggu keberhasilan penyelenggaraan pendidikan di sekolah yang dipimpinnya, untuk itu komitmen kerja kepala sekolah dalam pengelolaan sekolah perlu dibina dan ditingkatkan.

Banyak faktor yang mempengaruhi komitmen kerja kepala sekolah, baik faktor internal maupun faktor eksternal (Amabile 1996 dan Mullins 1999). Faktor internal dapat berupa motivasi, pengalaman, minat terhadap pekerjaan, pengetahuan dan keterampilan atau kemampuan kerja kepala sekolah, sedangkan faktor eksternal dapat berupa budaya organisasi, iklim organisasi, kepemimpinan atasan, kelengkapan sarana dan prasarana dalam pelaksanan pekerjaan, serta insentif yang diterima atau diperoleh dalam melaksanakan tugas (Steers 2001; Mullins 1999 dan Taylor 2005). Faktor-faktor tersebut di atas mempengaruhi komitmen kerja seseorang dalam melaksanakan tugas

Organisasi yang memiliki budaya yang kuat mempunyai pengaruh yang bermakna bagi 
perilaku dan sikap anggotanya. Anggota organisasi akan berperilaku dan bersikap secara positif dalam organisasi kalau disokong oleh budaya organisasi yang kuat, sebaliknya seandainya budaya organisasi kurang menyokong maka perilakuku anggota organisasi juga tidak akan menunjang terhadap pencapaian tujuan organisasi. Sejalan dengan itu Hamid (2002); Taroreh (2009) dan Martadiredja (2010), mengungkapkan bahwa budaya organisasi mempunyai pengaruh yang signifikan terhadap komitmen kerja para anggota organisasi. Pendapat ini juga disokong oleh Moeljono (2003) dan Simons (2005), yang mengungkapkan bahwa budaya organisasi dapat meningkatkan komitmen kerja dalam organisasi tersebut. Budaya organisasi yang positif juga akan memotivasi pegawai untuk berperilaku yang positif dalam organisasi. Oleh karena itu perlu didorong agar pegawai dapat memahami dengan baik budaya yang berlaku dalam organisasi. Rodeyah (2004) dan Basita Ginting (2011), mengemukakan dengan tidak dipahaminya nilai-nilai yang berlaku dalam organisasi, menyebabkan kerjasama pada organisasi tersebut sukar dibina. Oleh karena itu setiap organisasi harus mengupayakan agar nilai dan norma yang dianuti organisasi harus dipahami oleh anggota organisasi. Sejalan dengan itu Salfen Hasri (2005), mengemukakan budaya organisasi di sekolah belum terbentuk dengan baik, ini terlihat dari tidak termotivasinya personel sekolah untuk melaksanakan tugas dengan baik. Pada bagian lain Salfen Hasri (2005) mengemukakan rendahnya komitmen kerja pegawai merupakan akibat dari kurang difahaminya nilai-nilai atau budaya organisasi oleh pegawai tersebut.

Di samping faktor budaya organisasi, insentif atau penghargaan yang didapatkan pegawai dalam melaksanakan pekerjaan juga akan berpengaruh terhadap motivasi dan komitmen kerja mereka. Pegawai yang merasa dihargai dalam bekerja akan berusaha untuk selalu bekerja dengan sebaik-baiknya (McDougall 2004 ; Armstrong dan Murlis 2013). Sebaliknya apabila pegawai merasa tidak dihargai dalam melaksanakan tugas, mereka akan bekerja apa adanya. Cherington, (2005) ; Amstrong (2005) dan Edwards (2000) mengemukakan insentif yang diterima seseorang dalam melaksanakan pekerjaan sangat berpengaruh terhadap perbaikan komitmennya dalam bekerja. Oleh karena itu pimpinan perlu memberikan insentif kepada pegawai dalam melaksanakan pekerjaan. Hal ini juga disokong oleh Dahlan Iskan (2013) yang mengemukakan bahwa insentif atau penghargan yang diterima pegwai dalam melaksanakan pekerjaan akan dapat meningkatkan motivasi dan komitmennya dalam bekerja. Pegawai akan termotivasi menghasilkan produktifitas kerja yang baik apabila pegawai tersebut memperoleh imbalan (reward) yang memadai atau sebanding dengan produktifitas kerjanya.

\section{METODOLOGI PENELITIAN}

\section{Jenis Penelitian}

Jenis penelitian ini berbentuk Mixed methods atau gabungan. Kaedah gabungan yang digunakan pada penelitian ini adalah concurrent embedded design atau gabungan tidak berimbang. Kedua-dua pendekatan tersebut digunakan secara bersama-sama, tetapi independen untuk menjawab masalah yang sejenis. Pada kajian ini pendekatan kuantitatif sebagai primer dan kualitatif sebagai skunder.

\section{Populasi dan Sampel Penelitian a.Populasi Penelitian}

Populasi penelitian ini adalah kepala sekolah menengah negeri (SMPN, SMAN dan SMKN) pada kota-kota dalam Provinsi Sumatera Barat yang berjumlah 150 orang. Penyebaran populasi berdasarkan kota dan jenis sekolah seperti pada tabel 1.

Tabel 1 Penyebaran Populasi Penelitian Berdasarkan Kota dan Jenis Sekolah

\begin{tabular}{|c|l|c|c|c|c|}
\hline \multirow{2}{*}{ No } & \multirow{2}{*}{ Kota } & \multicolumn{3}{c|}{ Populasi Kepala Sekolah } & \multirow{2}{*}{ Jumlah } \\
\cline { 3 - 5 } & & SMP Negeri & SMA Negeri & SMK Negeri & \\
\hline 1 & Padang & 39 & 16 & 11 & 66 \\
\hline 2 & Bukittinggi & 8 & 5 & 2 & 15 \\
\hline 3 & Solok & 6 & 4 & 3 & 13 \\
\hline 4 & Sawahlunto & 6 & 2 & 2 & 10 \\
\hline 5 & Payakumbuh & 5 & 4 & 3 & 18 \\
\hline 6 & Padang Panjang & 5 & 3 & 2 & 10 \\
\hline
\end{tabular}




\begin{tabular}{|c|l|c|c|c|c|}
\hline 7 & Pariaman & 9 & 5 & 4 & 18 \\
\hline & Keseluruhan & $\mathbf{8 4}$ & $\mathbf{3 9}$ & $\mathbf{2 7}$ & $\mathbf{1 5 0}$ \\
\hline
\end{tabular}

Oleh karena populasi pada penelitian jumlahnya cukup besar, maka dilakukan pengambilan sampel

\section{b. Sampel Penelitian}

Pengambilan sampel pada penelitian ini dilakukan dengan teknik proporsional random sampling. Besarnya sampel ditentukan sebanyak $75 \%$ dari populasi, ini dilakukan karena jumlah $n$ pada penelitian ini hanya 150 orang, Krejcie dan Morgan (1970). Sedangkan untuk menetapkan responden dilakukan secara acak. Bagi jenis sekolah yang jumlah populasinya hanya dua orang, kedua-duanya diambil sebagai sampel. Sehingga setelah pembulatan diperoleh sampel sebanyak 116 orang. Penyebaran sampel berdasarkan kota dan jenis sekolah seperti pada tabel 2 .

Tabel 2 Penyebaran Sampel Berdasarkan Jenis Sekolah

\begin{tabular}{|c|l|c|c|c|c|}
\hline \multirow{2}{*}{ No Kota } & \multirow{2}{*}{ Kota } & \multicolumn{3}{c|}{ Sampel Kepala Sekolah } & \multirow{2}{*}{ Jumlah } \\
\cline { 3 - 5 } & & SMP Negeri & SMA Negeri & SMK Negeri & \\
\hline 1 & Padang & 29 & 12 & 9 & 50 \\
\hline 2 & Bukittinggi & 6 & 4 & 2 & 12 \\
\hline 3 & Solok & 5 & 3 & 2 & 10 \\
\hline 4 & Sawahlunto & 8 & 2 & 2 & 9 \\
\hline 5 & Payakumbuh & 4 & 2 & 2 & 14 \\
\hline 6 & Padang Panjang & 7 & 4 & 3 & 7 \\
\hline 7 & Pariaman & $\mathbf{6 4}$ & $\mathbf{3 0}$ & $\mathbf{2 2}$ & $\mathbf{1 1 6}$ \\
\hline & Keseluruhan & & & & \\
\hline
\end{tabular}

\section{Instrumen Penelitian}

Instrumen yang digunakan dalam penelitian ini yaitu angket dan panduan wawancara. Angket digunakan untuk mendapatkan jawaban dari responden secara kuantitatif, sedangkan panduan wawancara digunakan untuk mendapatkan jawaban responden secara kualitatif.

\section{Pengolahan Data}

Data kuantitatif pada penelitian ini diolah dengan menggunakan Regresi Ganda (stepwise) yang digunakan untuk mengetahui sumbangan variabel bebas terhadap variabel terikat, dengan formula :

$$
\begin{aligned}
& \tilde{Y}=\alpha+\beta_{1} X_{1}+\beta_{2} X_{2}+\varepsilon \\
& \alpha \quad=\text { konstanta (intercept) } \\
& \beta_{1}, \beta_{2} \quad=\text { koefisyen masing-masing variabel }
\end{aligned}
$$

Y

sekolah

$$
\begin{array}{ll}
X_{1} & =\text { data budaya organisasi } \\
X_{2} & =\text { data pemberian insentif } \\
\varepsilon & =\text { error standard }
\end{array}
$$

Sedangkan untuk data kualitatif diolah dengan analisis tematik.

\section{HASIL PENELITIAN DAN PEMBAHASAN \\ 1. Hipotesis Pertama}

Budaya organisasi $\left(\mathrm{X}_{1}\right)$ merupakan peramal terhadap komitmen kerja kepala sekolah (Y). Analisis ujian regresi variabel budaya organisasi kepada komitmen kerja kepala sekolah, seperti pada tabel 3 berikut.

Tabel 3 Analisis Uji regresi

Model Summary ${ }^{\mathrm{b}}$

\begin{tabular}{|c|c|c|c|c|}
\hline Mode & $\mathrm{R}$ & $\mathrm{R}$ Square & $\begin{array}{c}\text { Adjusted R } \\
\text { Square }\end{array}$ & $\begin{array}{c}\text { Std. Error of } \\
\text { The Estimate }\end{array}$ \\
\hline 1 & $.388^{\mathrm{a}}$ & .151 & .143 & 5.627 \\
\hline
\end{tabular}

a. Predictors : (Consultant), budaya Organisasi

b. Dependen variable : komitmen kerja kepala sekolah 
Pada tabel 3 di atas terlihat bahwa besarnya pengaruh variabel budaya organisasi $\left(\mathrm{X}_{1}\right)$ terhadap variabel komitmen kerja kepala sekolah $(\mathrm{Y})$ adalah $15.1 \%$ sedangkan sisanya dipengaruhi oleh faktor lain. Koefisien regresi pengaruh budaya organisasi terhadap komitmen kerja kepala sekolah, di kemukakan pada tabel 4 berikut.

Tabel 4 Koefisien Regresi pengaruh Budaya Organisasi terhadap Komitmen Kerja Kepala Sekolah

\begin{tabular}{|c|c|c|c|c|c|}
\hline \multirow{2}{*}{ Model } & \multicolumn{2}{|c|}{$\begin{array}{c}\text { Unstandardized } \\
\text { Coefficients }\end{array}$} & $\begin{array}{c}\text { Standardized } \\
\text { Coefficients }\end{array}$ & \multirow{2}{*}{$\mathrm{t}$} & \multirow{2}{*}{ Sig. } \\
\cline { 2 - 4 } & $\mathrm{B}$ & Std. Error & Beta & & \\
\hline 1 (constant) & 60.785 & 13.943 & & 4.360 & .000 \\
Budaya Organisasi & .355 & .079 & .388 & 4.499 & .000 \\
\hline
\end{tabular}

a. Dependent variable : Komitmen kerja kepala sekolah

Dari tabel 4 di atas diketahui bahwa kolom B pada constant adalah 60.785 , nilai budaya organisasi adalah 0.355 persamaan regresinya adalah $\mathrm{Y}=\mathrm{a}+\mathrm{bx}$ atau $60.785+0.355 \mathrm{x}$. Ini berarti bahwa setiap penambahan 1 nilai budaya organisasi, maka nilai komitmen kerja kepala sekolah akan bertambah sebesar 0.355. Selain itu tabel 4 di atas juga memperlihatkan signifikansi dengan uji t, untuk mengetahui pengaruh nyata budaya organisasi $\left(\mathrm{X}_{1}\right)$ secara sendiri (partial) terhadap komitmen kerja kepala sekolah (Y).

Hipotesis pertama $\left(\mathrm{Ha}_{1}\right)$ adalah budaya organisasi merupakan peramal kepada komitmen kerja kepala sekolah menengah negeri di kota-kota dalam Provinsi Sumatera Barat. Pada tabel 4 di atas diketahui bahwa nilai t hitung $=4.499$ dengan nilai signifikansi $0.000<0.05$, maka $\mathrm{Ha}_{1}$ diterima yang berarti budaya organisasi merupakan peramal kepada komitmen kerja kepala sekolah menengah negeri di kota-kota dalam Provinsi Sumatera Barat.

\section{Hipotesis Kedua}

Pemberian insentif $\left(\mathrm{X}_{2}\right)$ merupakan peramal terhadap komitmen kerja kepala sekolah (Y). Analisis uji regresi variabel pemberian insentif kepada komitmen kerja kepala sekolah dapat dilihat pada tabel 5 berikut.

Tabel 5 Analisis Ujian regresi

\begin{tabular}{|c|c|c|c|c|}
\hline Mode & $\mathrm{R}$ & $\mathrm{R}$ Square & $\begin{array}{c}\text { Adjusted R } \\
\text { Square }\end{array}$ & $\begin{array}{c}\text { Std. Error of } \\
\text { The Estimate }\end{array}$ \\
\hline 1 & $.540^{\mathrm{a}}$ & .292 & .286 & 5.138 \\
\hline
\end{tabular}

a. Predictors : (Consultant), pemberian insentif

b. Dependen variable : Komitmen kerja kepala sekolah

Dari tabel 5 di atas diketahui bahwa pengaruh variabel pemberian insentif $\left(\mathrm{X}_{2}\right)$ terhadap variabel komitmen kerja kepala sekolah (Y) adalah $29.2 \%$ sedangkan sisanya dipengaruhi oleh faktor lain. Koefisien regresi pengaruh pemberian insentif terhadap komitmen kerja kepala sekolah, di kemukakan pada tabel 6 berikut.

Tabel 6 Koefisien Regresi pengaruh Pemberian Insentif terhadap Komitmen Kerja Kepala Sekolah

\begin{tabular}{|c|c|c|c|c|c|}
\hline \multirow{2}{*}{ Model } & \multicolumn{2}{|c|}{$\begin{array}{c}\text { Unstandardized } \\
\text { Coefficients }\end{array}$} & $\begin{array}{c}\text { Standardized } \\
\text { Coefficients }\end{array}$ & \multirow{2}{*}{$\mathrm{t}$} & \multirow{2}{*}{ Sig. } \\
\cline { 2 - 6 } & $\mathrm{B}$ & Std. Error & Beta & & \\
\hline 1 (constant) & 83.605 & 5.835 & & 14.327 & .000 \\
Pemberian Insentif & .580 & .085 & .540 & 6.855 & .000 \\
\hline
\end{tabular}

b. Dependent Variable : Komitmen kerja kepala sekolah 
Pada tabel 6 di atas diketahui bahwa kolom B pada constant adalah 83.605 , nilai pemberian insentif adalah 0.580 persamaan regresinya adalah $\mathrm{Y}=\mathrm{a}+\mathrm{bx}$ atau $83.605+0.580 \mathrm{x}$. Ini berarti bahwa setiap penambahan 1 nilai pemberian insentif, maka nilai komitmen kerja kepala sekolah akan bertambah sebesar 0.580 . Selain itu tabel 6 di atas juga memperlihatkan signifikansi dengan uji t, untuk mengetahui pengaruh nyata pemberian insentif $\left(\mathrm{X}_{2}\right)$ secara sendiri (partial) terhadap komitmen kerja kepala sekolah (Y).

Hipotesis kedua $\left(\mathrm{Ha}_{2}\right)$ adalah pemberian insentif merupakan peramal kepada komitmen kerja kepala sekolah menengah negeri di kota-kota dalam Provinsi Sumatera Barat. Pada tabel 6 di atas diketahui bahwa nilai $\mathrm{t}$ hitung $=6.855$ dengan nilai signifikansi $0.000<0.05$, maka $\mathrm{Ha}_{2}$ diterima yang berarti pemberian insentif merupakan peramal kepada komitmen kerja kepala sekolah sekolah menengah negeri di kota-kota dalam Provinsi Sumatera Barat.

\section{Hipotesis Ketiga}

Budaya organisasi $\left(\mathrm{X}_{1}\right)$ dan pemberian insentif $\left(\mathrm{X}_{2}\right)$ merupakan peramal terhadap komitmen kerja kepala sekolah (Y). Analisis uji regresi variabel budaya organisasi $\left(\mathrm{X}_{1}\right)$ dan pemberian insentif $\left(\mathrm{X}_{2}\right)$ kepada komitmen kerja kepala sekolah (Y) dapat dilihat pada tabel 7 berikut.

Tabel 7 Analisis Ujian regresi

\begin{tabular}{|c|c|c|c|c|}
\hline Mode & $\mathrm{R}$ & $\mathrm{R}$ Square & $\begin{array}{c}\text { Adjusted R } \\
\text { Square }\end{array}$ & $\begin{array}{c}\text { Std. Error of } \\
\text { The Estimate }\end{array}$ \\
\hline 1 & $.595^{\mathrm{a}}$ & .353 & .342 & 4.932 \\
\hline
\end{tabular}

a. Predictors : (Consultant), budaya organisasi dan pemberian insentif

b. Dependen variable : Komitmen kerja kepala sekolah

Pada tabel 7 di atas dapat dilihat bahwa pengaruh variabel budaya organisasi $\left(\mathrm{X}_{1}\right)$ dan pemberian insentif $\left(\mathrm{X}_{2}\right)$ terhadap komitmen kerja kepala sekolah (Y) adalah 35.3\%, sedangkan sisanya dipengaruhi oleh faktor lain. Koefisien regresi pengaruh budaya organisai dan pemberian insentif terhadap komitmen kerja kepala sekolah, di kemukakan pada tabel 8 berikut.

Tabel 8 Koefisien Regresi pengaruh Budaya Organisasi dan Pemberian Insentif terhadap Komitmen Kerja Kepala Sekolah

\begin{tabular}{|c|r|r|r|r|r|}
\hline \multirow{2}{*}{ Model } & \multicolumn{2}{|c|}{$\begin{array}{c}\text { Unstandardized } \\
\text { Coefficients }\end{array}$} & \multicolumn{1}{c|}{$\begin{array}{c}\text { Standardized } \\
\text { Coefficients }\end{array}$} & \multirow{2}{*}{$\mathrm{t}$} & \multicolumn{1}{c|}{ Sig. } \\
\cline { 2 - 4 } & \multicolumn{1}{|c|}{$\mathrm{B}$} & Std. Error & \multicolumn{1}{c|}{ Beta } & & \\
\hline 1 (Constant) & 47.207 & 12.431 & & 3.798 & .000 \\
Budaya Organisasi & .236 & .072 & .258 & 3.280 & .001 \\
Pemberian Insentif & .503 & .085 & .469 & 5.951 & .000 \\
\hline
\end{tabular}

a. Dependen Variable : Komitmen kerja kepala sekolah

Pada tabel 8 di atas, dapat dilihat bahwa nilai konstanta yang diperoleh adalah 47.207, koefisien persamaan regresi variabel budaya organisasi $\left(\mathrm{X}_{1}\right) \quad 0.236$ dan variabel pemberian insentif $\left(\mathrm{X}_{2}\right)$ adalah 0.503 , tingkat signifikan kedua variabel ini lebih kecil daripada alpha 0.05 yang dipersyaratkan iaitu 0.001 untuk variabel budaya organisasi dan 0.000 untuk variabel pemberian insentif. Dengan demikian dapat dikatakan bahwa nilai koefisien persamaan regresi yang diperoleh diketahui bahwa variabel budaya organisasi dan pemberian insentif dapat digunakan untuk meramalkan komitmen kerja kepala sekolah menengah negeri pada kota-kota dalam Provinsi Sumatera Barat. 
Selanjutnya dapat dijelaskan bahwa nilai konstanta yang diperoleh adalah 47.207 mengidentifikasikan bahwa jika tidak diikutkan budaya organisasi dan pemberian insentif, maka skor komitmen kerja kepala sekolah yang diperoleh sebesar 47.207. Sedangkan nilai koefisien persamaan regresi pada masing- masingnya adalah 0.236 dan 0.503. Ini menunjukkan bahwa jika variabel budaya organisasi $\left(\mathrm{X}_{1}\right)$ dan pemberian insentif $\left(\mathrm{X}_{2}\right)$ ditingkatkan sebesar 1 (satu) satuan, maka akan dapat meningkatkan nilai skor komitmen kerja kepala sekolah (Y) masingmasingnya sebesar $=0.236+0.503 \times 1=0.739$.

Bedasarkan hasil analisis ini maka diperoleh persamaan regresi ganda $\tilde{Y}=a+b_{1} x_{1}+$ $\mathrm{b}_{2} \mathrm{x}_{2}$, dimana $\mathrm{a}=47.207$ dan $\mathrm{b}_{1}=0.236, \mathrm{~b}_{2}=0.503$ sehingga model persamaan regresi komitmen kerja kepala sekolah berdasarkan faktor budaya organisasi dan pemberian insentif adalah $\tilde{\mathbf{Y}}=$ $47.207+0.236 x_{1}+0.503 x_{2}$.

\section{SIMPULAN}

Hasil penelitian ini menunjukkan bahwa budaya organisasi dan pemberian insentif baik secara sendiri-sendiri maupun secara bersama-sama dapat menjadi prediktor atau faktor peramal terhadap komitmen kerja kepala sekolah. Oleh karena itu untuk meningkatkan komitmen kerja kepala sekolah dalam melaksanakan tugas, budaya organisasi di sekolah perlu diperbaiki dan juga perlu diberikan insentif kepada kepala sekolah yang berhasil dalam melaksanakan tugas.

\section{DAFTAR PUSTAKA}

Armstrong, Michael and Helen Murlis. (2013). Reward Management: A Hand book of Remuneration Strategy and Practice. London: Kogan Page.

Armstrong, Michael. (2005). Personnel Management Practice. Kogan Page: London.

Barrows, D. and Wesson, T. (2001). A Comparative Analysis of Job Satisfaction among Public and Private Sector Professional. Toronto: Diakses 29 Juli 2005.

Basita Ginting (2011). Hubungan Budaya Oraganisasi di Sekolah dan Kepemimpinan Kepala Sekolah dengan Kinerja Guru
SMAN Kota Binjai, (tesis). Medan: Unimed.

Cherrington, D. J. (2005). Organization Behavior; The Management of Individual and Organizational Performance. New York : A Division of Simon of Schulter Inc.

Dahlan Iskan. (2013). Manufacturing Hope: Memberikan Harapan dengan Pujian. Jakarta : Alex Media Computindo.

Dessler, Garry. (2005). Manajemen Personalian (terjemahan Agus Dharma). Edisi Ketiga. Erlangga: Jakarta.

Donaldson. Lex and James H. Davis. (2006). Stewerdship Theory or Agency Theory: CEO Governance and Shareholders Returns. Australian Journal of Management, Volume 16, p 49-56

Drake, Thelbert L. and William H. Roe. (1999). Principalship. New York : Macmillan Publishing Company.

Hamid, A. (2002). Pengaruh Budaya Organisasi terhadap Motivasi dan Prestasi Kerja di PT Nusantara IV (Persero) Sumatera Utara, (disertasi). Surabaya: Universitas Airlangga.

Imam Subandi. (2012). Pengaruh Komitmen Tugas, Pemberdayaan dan Motivasi Kerja terhadap Kinerja Pengawas Sekolah, (disertasi). Jakarta: Pasca Sarjana UNJ.

Martadiredja, Tutty S. (2010). Pengaruh Budaya Organisasi, Kompetensi, dan Motivasi Kerja Terhadap Kinerja Dosen. Disertasi. Bandung : Universitas Pajajaran.

McDougall, G. H. Lovesque T. (2004). Customer Satisfaction With Services. Putting Perceived Value Into the Eguation. Journal of Services Maeketing. 14 pg, 392-410.

Moeljono, Djokosantoso (2003). Cultured! Budaya Organisasi dalam Tantangan.

Moon, M. J. (2000). Organizational Commitment Revisited in New Public Management: Motivation, Organizational Culture, Sector 
and Managerial Grid. Public Performance and Management Review, 24(2): 174-194.

Mowday, R. T., Porter, L.W., \& Steers, R.M. (2002). Employee Organization Linkages: The Psychology of Commitment, Absenteeism, and Turnover.

Mullins, L. J. (1999). Management Organisational Behavior. Great Britain: Prentice Hall. Natriello, D., \& Dombusch, N.

Mulyasa. (2013). Kepala sekolah yang Profesional. Bandung: Alfabeta.

Nurliana. (2011). Pengaruh Budaya Organisasi, Kepemimpinan, Kepuasan Kerja dan Motivasi Berprestasi terhadap Komitmen Organisasi Kepala-kepala SDN di Kota Palembang. (disertasi). Jakarta: Pasca sarjana UNJ.

Robbins, Stephen P. (2005). Organizational Behavior; Concepts, Controversies and Application, 2nd ed. Toronto: Prentice Hall Inc.

Rodeyah. (2004). Pengaruh Kepemimpinan Kepala Sekolah terhadap Komitmen Kerja Guru. Cianjur: Arena.
Salfen Hasri. (2005). Manajemen Pendidikan: Pendekatan Nilai dan Budaya Organisasi. Makasar : YAPMA.

Sopiah. (2008). Perilaku Organisasi. Yogyakarta : Andi.

Steers, R. M. (2001). Antecedents and Outcomes of Organizational Commitment. Administrative Science Quarterly.

Taroreh, Nita Norce. (2009). Analisis FaktorFaktor Organisasional yang Mempengaruhi Kinerja Dosen Ekonomi PTN Di Sulawesi Utara. (disertasi). Pasca Sarjana Universitas Negeri Malang.

Taylor, J. W, V. (2005). Leadership Style, School Climate and Institutional Commitment of Teachers. International Forum.

Wahjosumidjo. (2013). Kepemimpinan Kepala Sekolah. Jakarta: Raja Grafindo Persada.

Yuni Purwanti. (2012). Pengaruh Karakteristik Pekerjaan, Kebijakan Organisasi dan Kepuasan Kerja Terhadap Komitmen Organisasi Pegawai Kementerian Pemuda dan Olahraga Republik Indonesia. (disertasi). Jakarta: Pasca Sarjana UNJ. 